\title{
Determining Factors in the Use of Digital Marketing and Its Effect on Marketing Performance in the Creative Industries in Tasikmalaya
}

\author{
Gun Gun Gunawan', Maman Sulaeman ${ }^{2}$ \\ ${ }^{1,2}$ Polytechnic of Triguna, Tasikmalaya, Indonesia \\ mansulaeman1274@gmail.com
}

\begin{abstract}
The economic development of creative industries is an important aspect as a potentially good force for the national economy for the future. However, the creative industry in Tasikmalaya lacks product innovation, still maintaining the authenticity of its products by $67 \%$, products that are easily replicated by $83 \%$. Utilization of digital marketing concepts provides hope for MSMEs to develop into economic power centers. This research aims to analyze the determining factors of digital marketing usage and its influence on digital marketing in the creative industries in Tasikmalaya. This research is categorized as explanatory research which is a study that aims to explain the causal relationship between variables through hypothesis testing. The Inference Statitic method used in the analysis of this research data is the path of analysis. The results showed knowledge of ICT (Information and Communication Technology) adoption had a significant effect on digital marketing. Innovation has a significant impact on digital marketing. Digital marketing is influenced by the knowledge of ICT adoption and Innovation. Knowledge of ICT adoption and innovation affects digital marketing through digital marketing.
\end{abstract}

Keywords knowledge; information technology; digital marketing

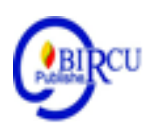

\section{Introduction}

The rapid growth of technology has now enabled the internet to become one of the rapidly evolving advances in information technology. According to The World Bank (2018), the percentage of the population of internet users in Indonesia and Malaysia has increased. Daily internet usage is increasing, business people need to be aware of the issue. Nowadays, many businesspeople create websites, blogs, or create accounts on facebook, instagram, or twitter to market or promote their products. This progress is considered very useful to be used as a business marketing strategy that is also carried out by micro and medium enterprises (MSMEs).

Digital marketing is considered effective to be applied by MSMEs in marketing their products. Mujiana and Abdul (2012) said, one of the competitiveness that MSMEs must have is the mastery of information technology. Digital marketing can be an opportunity for MSMEs in getting consumer attention. Icha (2016) also states that the fastest way to get attention from consumers and in a wide variety of ways in which organizations have been found to connect with their consumers is through social media. Purwana et al. (2017) further states that digital marketing is a promotional activity and market search through digital media online by utilizing various means such as social networking. Cyberspace is now no longer only able to connect people with devices, but also people with others all over the world. Digital marketing makes it easy for businesspeople to monitor and provide all the needs and desires of potential consumers, potential consumers can also search and get product information just by browsing the virtual world so as to facilitate the search process. Based on 
previous explanations, it can be said that consumers today are increasingly independent in selecting and sorting products and making purchasing decisions based on their search results through social media.

According to a survey conducted by PT MARS Indonesia in 2011 between 1-718 MSMEs in eight major cities in Indonesia, namely Jabodetabek, Bandung, Semarang, Yogyakarta, Solo, Surabaya, Medan, and Makasar, as many as $67 \%$ of MSMEs use email for their business activities while $33 \%$ of them do not use at all. Regarding the use of the website, $70 \%$ of MSMEs have it and only $29.5 \%$ do not. According to Demishkevich's research (2015), it is important to know the rate of adoption of internet marketing among small businesses; understanding the breadth and effectiveness of the usefulness of internet marketing tools is very important. In general, there are gaps in academic research related to how small businesses utilize channels and marketing tools over the internet.

The creative industry in Tasikmalaya lacks product innovation, which still maintains the authenticity of its products by $67 \%$, products produced by SMEs in Tasikmalaya are easily replicated by $83 \%$. Bank Indonesia's 2017 study shows that the competitiveness of MSMEs in Tasikmalaya remains low. Empowerment of SMEs needs to be made efforts to improve the quality of products, market access, and the proper utilization of technology, in order to make a positive impact and can be felt by the surrounding community. Based on the above description we are interested in conducting research on: Determining The Use of Digital Marketing And Its Effect on The Targeting Performance in The Creative Industry in Tasikmalaya.

\section{Review of Literatures}

The development of information technology is rapidly evolving. Various small to large business activities utilize this development to run their business. The number of competitors is a consideration for entrepreneurs to enter into very tight competition. The right marketing and media strategy is used to be able to reach the intended market so that sales volume is always increasing and profit. Digital Marketing is one of the marketing media that is currently in demand by the public to support various activities carried out. They are little by little starting to abandon the convesional/traditional marketing model of switching to modern digital marketing. With digital marketing communication and transactions can be done at any time/real time and can be global or global. With this large number of chat-based social media users and increasingly increasing days it opens up opportunities for SMEs to develop their markets.

Actually e-marketing is a development of traditional marketing where traditional marketing is a marketing process through offline communication media such as through the spread of brochures, advertising on television and radio, and so on. After the rise of the internet and the ease of communication offered, then the application of marketing to the company began to adopt internet media, which was then referred to as e-marketing. While according to Kotler in Widodo (2012) internet marketing has five big advantages for companies that use it. First, both small companies and large corporations can do so. Second, there are no real limits in the advertising space when compared to print and broadcast media. Third, access and search for information is very fast when compared to express mail or even faxes. Fourth, the site can be visited by anyone, anywhere in the world, at any time. Fifth, shopping can be done faster and alone.

Sarwono and Prihartono (2012) suggested that techniques that facilitate access and publication of information using social interaction through social media. Then Aloysius Bagas Pradipta Irianto in his journal entitled the utilization of social media to increase the 
market share of SMEs said, At this time there are two types of marketing, namely offline marketing or traditional marketing done by looking for customers or clients through meeting directly with those who may be interested in becoming customers or clients. Other marketing uses websites as marketing media known as online marketing. From a business point of view, social media is about allowing conversation. Social media is also about how this conversation can be generated, promoted, and made revenue (Safko, 2013).

Social media is a place, a tool, a service that allows individuals to express themselves to meet and share with other colleagues through internet technology. Social media is a phase of change in how people discover, read, talk, and share information, news, data with others. Social media became very popular because of its ease and gave people the opportunity to be able to connect online in the form of personal, political and business activities. Social media provides social communication services. (Kartika, 2013): According to Strauss and Frost (2013), the seven stages in the design of e-marketing are Situation Analysis, EMarketing Strategic Planning, Objectives, E-Marketing Strategy, Implementation Plan, Budget, Evaluation Plan.

The impact of social media is very real on the increase in website traffic and the increase in online sales (Solis, 2010). Social media has been used as one of the means used to do product marketing or commonly referred to as social media marketing. Social media marketing is a process that encourages individuals to promote through their websites, products, or services through online social channels and to communicate by utilizing a much larger community that is more likely to do marketing than through traditional advertising channels (Weinberg, 2013:3-4). Social media marketing is a form of online advertising that uses the cultural context of social communities including social networks, virtual worlds, social news sites, and social opinion sharing sites to meet communication purposes (Tuten, 2014:19).

Content Creation can be seen from the creation of interesting content and can represent the personality of a business in order to be trusted by the target consumer. Content creation will help consumers shape credibility, relationships and loyalty. Content Sharing can help expand a business's network and expand its online audience. Content sharing can create a good opportunity to get attention and be remembered by online audiences and can lead to indirect and direct sales depending. Connecting is an intertwined relationship between the giver and the recipient of the message who share the same interests. The intertwined relationship between the giver and the recipient of the message can result in more business. Community Building aims to find target consumers who have an interest in the products and services they offer by having interactions with each other and establishing relationships with them (Gunelius, 2011).

Online marketing is suitable for newly pioneered businesses. Certainly cost-effective, because it does not have to hold a place / outlet to display its products / services, can be selfcontrolled without having to recruit unlimited employees, time or hours, and have a wide market reach, since online marketing is usually supported by the existence of websites or social media (facebook, instagram, WA, etc.) Indonesian Internet Service Providers (APJII) in 2014, stating that internet users in Indonesia are dominated by 18-25 year olds, almost half of the total number of internet users in Indonesia (49\%). This can be interpreted as internet users in Indonesia belongs to the category of digital natives group. This age category has a very active character using digital technology networks and has proficiency in operating internet-based technology (Nursatyo, 2018). The world's internet users currently reach 3.773 billion and social media users have reached 2.789 billion and for Indonesia itself the number of internet users has reached 132 million active internet users and 106 million social media users, (Kominfo, 2017). Of the 106 million social media users in Indonesia Youtube is a 
highly in demand medium with $49 \%$ of users, followed by Facebook by $48 \%$, followed by Instagram at 39\%, Twitter 38\%, WhatsApp 38\%, Google 38\% (Mahardika \& Aji, 2018).

\section{Research Method}

This research is categorized as explanatory research, which aims to explain the causal relationship between variables through hypotheses test. This research approach is a survey approach. The populations in this study were all SMEs owners in Tasikmalaya Regency and City. The data taken about 3455 people from Tasikmalaya Industry and Trade Chamber in 2018 used simple random sampling technique then compressed with formulation to 375 people. The inferential statistical method used in the data analysis of this research is path analisys. Reasons for using path analisys, consideration that the causal relationship formulated in this study uses a non-simple model that has multiple roles such as variables. This form of causal relationship requires analysis that is able to explain simultaneously about the relationship so that the method used in this study uses path analisys.

\section{Discussion}

Variable of Knowledge adoption ICT (X1) and Innovation (X2) on Digital marketing $(\mathrm{Y})$ and its impact on Marketing Performance $(\mathrm{Z})$ can be seen in the following table:

Table 1. Knowledge of ICT (X1) adoption and Innovation (X2) to Marketing Performance (Z) Through Digital marketing (Y)

Coefficients $^{\text {a }}$

\begin{tabular}{|l|r|r|r|r|r|}
\hline \multirow{2}{*}{ Model } & \multicolumn{2}{|c|}{$\begin{array}{c}\text { Unstandardized } \\
\text { Coefficients }\end{array}$} & $\begin{array}{l}\text { Standardized } \\
\text { Coefficients }\end{array}$ & \multirow{2}{*}{$\mathrm{t}$} & \\
\cline { 2 - 4 } & \multicolumn{1}{|c|}{$\mathrm{B}$} & $\begin{array}{c}\text { Std. } \\
\text { Error }\end{array}$ & Beta & & \\
\hline (Constant) & 4.740 & 2.263 & & 2.095 & .041 \\
Knowledge ICT & .307 & .148 & .319 & 2.079 & .042 \\
1 Inovation & .311 & .151 & .316 & 2.058 & .044 \\
Digital Marketing & .298 & .094 & .326 & 3.151 & .003 \\
\hline
\end{tabular}

a. Dependent Variable: Marketing Performance 
Based on the data in Table 1 above, the relationship between Knowledge adoption ICT (X1) and Innovation (X2) to Marketing Performance (Z) through Digital marketing (Y) as followed:

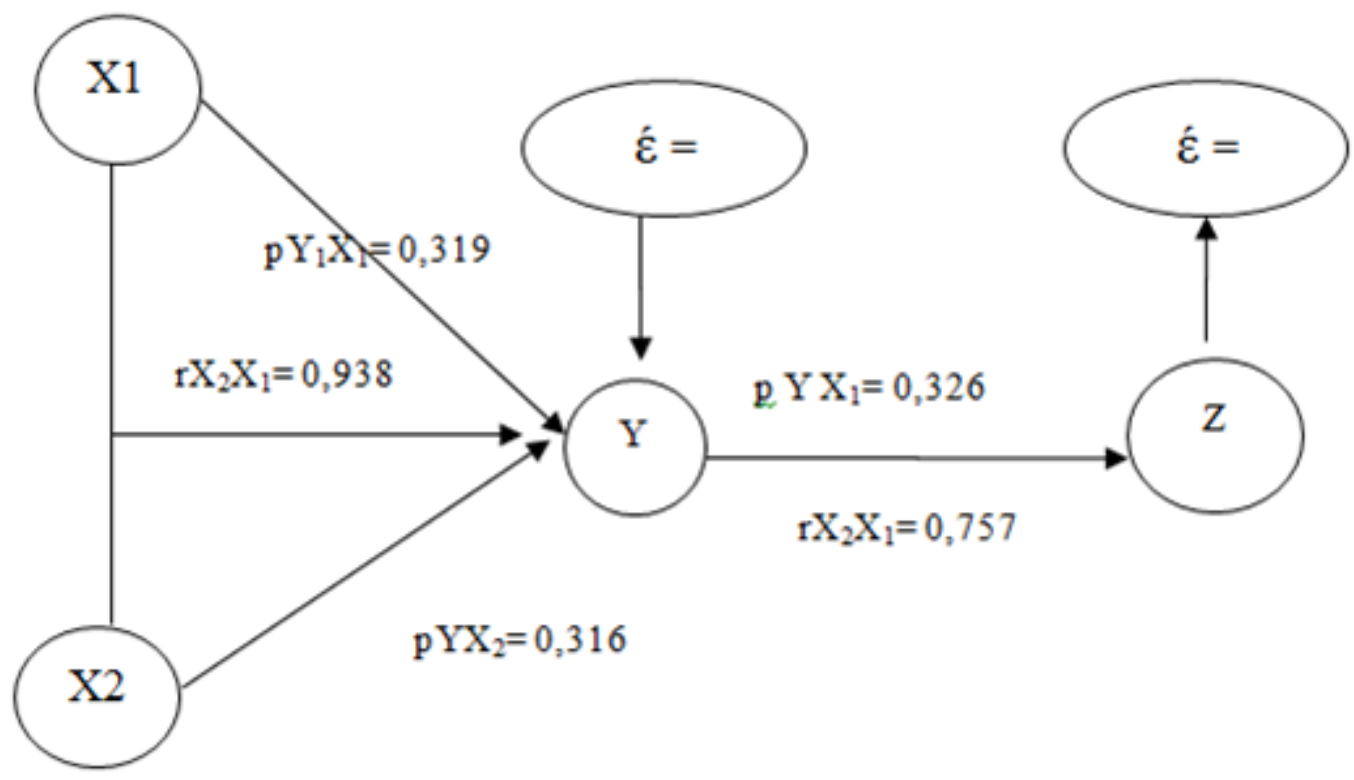

Figure 1. Relationship between Knowledge adoption ICT (X1) and Innovation (X2) to Marketing Performance (Z) through Digital Marketing (Y)

\subsection{Influence Knowledge of ICT Adoption and Innovation on Digital Marketing}

Based on the results of research shows that there is an influence of knowledge of ICT adoption and innovation on digital marketing. Understanding IT in SMEs is critical to improving the effectiveness and efficiency of the company. But it is unfortunate because in reality only a small number of SMEs understand this. Currently it is estimated that only $30 \%$ of the 56.5 million SMEs spread throughout Indonesia have knowledge of IT. THE use of IT provides positive value for management strategies related to communication aspects, information access, decision making, data management and knowledge management in an organization. IT can be a strategic strength and tool for organizations that benefit from the promotional aspects and the power of competitiveness. In adopting innovations that need to be considered that there are characteristics of innovation that are then taken into consideration by many individuals to decide whether to adopt or not. As an innovation by MSMEs, information technology has a number of advantages, including the opportunity to expand market access, as a marketing medium, and many more. Computers and communication tools are part of information technology (McKeown, 2009). McKeown added that information technology is a technology used to create, store, exchange, and use information in a variety of ways. William and Sawyer (2007) also argued that information technology was a combination of computers and communication.

Technological advances to date are growing rapidly. Many new discoveries in technology show how fast technology is progressing, from simple technology to cutting-edge technology. Utilization of information technology improves quality of life, and supports daily activities such as work, transportation, and entertainment as well as applies both to business and government. 


\subsection{Influence Knowledge of ICT Adoption and Innovation on Marketing Performance}

Based on the results of the study shows that there is an influence of knowledge of ICT adoption and innovation on the performance of the target. Adoption rates are the relative speed at which innovation is adopted by members of the social system. It is generally measured as the number of individuals who adopt a new idea within a certain period, such as each year. So adoption rates are numerical indicators of the steepness of the adoption curve for an innovation. The perceived attributes of an innovation are one of the important explanations of the adoption rate of an innovation. From 49 to 87 percent of the variance in adoption rates is explained by five attributes: Relative gain, compatibility, complexity, tlialability, and observability. In addition to the five perceived attributes of an innovation, other variables such as (1) the type of innovation decision, (2) the nature of communication channels that spread innovation at various stages in the innovation decision-making process, (3) the nature of the social system in which innovation spreads, and (4) the extent to which the agent's promotion efforts change in getting used to innovation, affecting the adoption rate of innovation (Rogers, 1995).

Technological innovation has been the subject of extensive theoretical and empirical studies and is now widely recognized as an important determinant of sustainable superior performance. Innovation is an idea, practice, or object that is considered new by an individual or other unit of adaptation. Innovation in ICT, not only refers to technological updates, but also refers to updates in terms of thought and action. Technological innovation consists of two related but different factors: (1) Finding innovation in existing ICT, (2) If it does not work, decide to adopt more advanced innovation (ICT). On the other hand, the adoption of technological innovation itself can be described as consisting of a sequence of 3 stages: initiation, adoption and implementation. At the initiation stage, information about technological innovation is collected and widely dievapan companies are required to create new ideas, new processes, new products to meet customer needs.

Innovation is the first dimension of entrepreneurial orientation. Innovation refers to the tendency of new ideas, novelty, experimentation, and creative processes that result in new technological processes, services, and products. Therefore, innovation is similar to a climate, culture or orientation is not the result. Innovation has a positive effect on marketing performance. That a culture that helps the development of the innovation process is central to the performance of new product development. Innovation needs to take into account the uniqueness of a product, thus the SME actors make it possible to create a product that differs from its rival alternatives assessed by customers in order to improve the performance of SMEs. One of the efforts that SMEs can make in product innovation is through the creation of environmentally friendly products. For example, the manufacture of environmentally friendly plastic bags that can be destroyed by themselves so as not to pollute the environment. In addition to the product side, innovation can be done in terms of technology used such as using environmentally friendly equipment during the production process, and so on

\subsection{The Influence of Digital Marketing on Marketing Performance}

Based on the results of research shows that there is an influence of digital marketing knowledge on the targeting performance of the development of information technology is very rapidly developed. Various small to large business activities utilize this development to run their business. The number of competitors is a consideration for entrepreneurs to enter into very tight competition. The right marketing and media strategy is used to be able to reach the intended market so that sales volume is always increasing and profit. Digital Marketing is one of the marketing media that is currently in demand by the public to support various activities carried out. They are little by little starting to abandon the convesional/traditional 
marketing model of switching to modern digital marketing. With digital marketing communication and transactions can be done at any time / real time and can be global or global.

Digital Marketing itself also has far-reaching implications for the interests of different elements of the mix for many markets, setting out whether companies are directly involved in e-commerce transactions. As a result, the marketing mix is a useful framework for informing strategy development. First, digital marketing provides a framework for comparing existing services with competitors and can also be used as a mechanism to generate alternative strategic approaches. Citing Harwindra Yoga Prasetya and Adi Nurmahdi, digital marketing (also called internet marketing or online marketing) is associated with direct marketing because companies that conduct these digital marketing activities can shorten their supply chains or supply chains, and can certainly reduce their operating costs. Reducing operating costs will certainly have a positive impact both for the company and for users as consumers.

\section{Conclusion}

1. Pengetahuan adopsi ICT and Inovasi influenced on Digital marketing, either partially or simultaneously,

2. Pengetahuan adopsi ICT and Inovasi influenced on Kinerja pemasaran, either partially or simultaneously,

3. Digital marketing influenced on Kinerja pemasaran partially.

\section{References}

Ahmad, M. (2020). Strengths and Weaknesses of Cognitive Theory. Budapest International Research and Critics Institute-Journal (BIRCI-Journal) Vol 3 (3): 1584-1593.

Agus. (2012). Komunikasi Pemasaran. Jakarta : Erlangga Jurnal Administrasi Bisnis (JAB)|Vol. 58 No. 1 Mei 2018| administrasibisnis.studentjournal.ub.ac.id 199

Alsubagh Helal. (2015). The Impact of Social Networks on Consumers Behaviours. International Journal of Business and Social Science. Vol. 6, No.1. pp 209-216

Arief, Giri Maulana. (2015). Pengaruh Social Media Marketing Melalui Instagram terhadap Minat Beli Konsumen Sugar Tribe. Jurnal Manajemen. Vol.2, No.3. Hal. 2581-2587

Bahtar, Azlin and Mazzini Muda. (2016). The Impact of User Generated Content (UGC) on Products Reviews towards Online Purchasing-A Conceptual Framework. Procedia Economics and Finance. Vol. 37. Pp 337-342

Chang, Chen. (2016). The Influence of Social Power in Online Purchase Decision. British Journal of Applied Science and Technology. Vol 12. No. 5. Pp 1-16

Dharmmesta, Basu Swastha dan Hani T Handoko. Manajemen Pemasaran Analisis Perilaku Konsumen. Edisi Pertama. Cetakan Kelima. Yogyakarta : BPFE Gunelius,

Hardey, Mariann. (2011). Generations C Content Creations, Connections, and Choice. International Journal of Market Research. Vol 53 Issue 6. Pp 749-770

Iblasi, Walid. (2016). The Impact of Social Media as a Marketing Tool on Purchasing Decisions (Case Study on Samsung for Electrical Home Appliances). International Journal of Managerial Studies and Research. Vol. 4. Issue. 1. Pp. 14-28

Karman, Melissa. (2015). The Impact of Social Media Marketing on Brand Equity toward the Purchase Intention of Starbucks Indonesia. Journal Management. Vol.3, No.2.pp.77-88

Kotler, Philip dan Gary Armstrong. (2012). PrinsipPrinsip Pemasaran. Diterjemahkan oleh : Bob Sabran. Edisi keduabelas. Jilid 2. Jakarta : Erlangga 
Marbun, D.S., Juliandi, A., and Effendi, S. (2020). The Effect of Social Media Culture and Knowledge Transfer on Performance. Budapest International Research and Critics Institute-Journal (BIRCI-Journal) Vol 3 (3): 2513-2520.

Nurfitriani. (2016). Pengaruh Social Media Marketing melalui Official Account LINE Alfamart terhadap Minat Beli Konsumen. Jurnal Online Mahasiswa Bidang Ilmu Sosial dan Ilmu Politik. Vol.3. No.2. Hal. 15-16

O’ Reilly Zimmerman, Dan and Doug Sahlin. (2010). Social Media Marketing All in One for Dummies. New Jersey : Wiley Publishing Jurnal :

Pane, I.F., and Suwantoro, H. (2019). The Study of Indisch Architecture Development as an Effort in Preserving the Heritage of Colonial History in Medan. Budapest International Research and Critics Institute-Journal (BIRCI-Journal) Vol 2 (4): 207-214.

Ramlan, Farizawati, Hasrul, S. (2020). The Effectiveness of Implementation of the MGM Revitalization Program as a Media Increasing English Teacher Competency in Pidie District. Budapest International Research and Critics Institute-Journal (BIRCI-Journal) Vol 3 (1): 95-103.

Solis, Brian. (2010). Engage : The Complete Guide for Brands and Businesses to Build, Cultivate, and Measure Success in the New Web. New Jersey : Wiley

Sulaeman, Maman, Establish a Competitive Advantage with Market Sensing Capability, Distinctive Competence and Product Innovation for Performance Marketing and Sustainability Efforts, Journal of Physics: Conference Series, Volume 1477, Science https://iopscience.iop.org/article/10.1088/1742-6596/1477/7/072019/meta.

Sumarwan, Ujang. (2014). Perilaku Konsumen : Teori dan Penerapannya dalam Pemasaran. Bogor : Ghalia Indonesia.

Susan. (2011). Minute Social Media Marketing. United States : McGraw Hill Hermawan.

Tuten, Tracy L. (2014). Advertising 2.0 Social Media Marketing in a Web 2.0 World. Connecticut : Praeger.

Weinberg, Tamar. (2013). The New Community Rules: Marketing on the Social Web. California:

Zanjabila, Ridwan. (2017). Analisis Pengaruh Social Media Marketing terhadap Keputusan Pembelian (Studi pada Pelanggan Bandung Techno Park 2017). Jurnal Ilmiah Mahasiswa Fakultas Ilmu Terapan. 